\title{
Tomasz Drabowicz Ruchliwość społeczna jako przedmiot badań socjologicznych - podstawowe pojęcia i koncepcje, cele i znaczenie badań
}

\section{Sociological research on social mobility: concepts, aims, policy relevance}

The article discusses the key theories, concepts, and notions used in comparative research into intergenerational social class mobility. More specifically, it discusses the Featherman, Jones, and Hauser hypothesis about cross-national similarity in social class mobility, describes a distinction between absolute and relative social mobility, and presents the Erikson-Goldthorpe-Portocarero class scheme. After discussing the results of both classical and recent studies on intergenerational social class mobility, this paper deals with the evidence-based policy recommendations relevant for decision-makers who can influence within certain limits the extent to which the rate of intergenerational social mobility can be equalised.

\begin{tabular}{r|l}
\hline DOI & https://doi.org/10.31268/StudiaBAS.2020.10 \\
\hline Słowa kluczowe & $\begin{array}{l}\text { badania porównawcze, klasa społeczna, nierówności społeczne, } \\
\text { ruchliwość społeczna, równość szans, struktura społeczna }\end{array}$ \\
\hline Keywords & $\begin{array}{l}\text { comparative research, social class, social inequality, social mobility, } \\
\text { equality of opportunity, social structure }\end{array}$ \\
\hline O autorze & $\begin{array}{l}\text { doktor habilitowany, kierownik Katedry Socjologii Struktur i Zmian } \\
\text { Społecznych na Wydziale Ekonomiczno-Socjologicznym Uniwersytetu } \\
\text { Łódzkiego } \cdot \Delta \text { tomasz.drabowicz@uni.lodz.pl • } \\
\text { ORCID 0000-0002-7925-696X }\end{array}$ \\
\hline
\end{tabular}

\section{Wstęp}

Celem tego artykułu będzie przedstawienie podstawowych pojęć (ruchliwość absolutna i ruchliwość względna/płynność społeczna) i koncepcji (hipoteza Feathermana, Jonesa i Hausera, schemat klasowy Eriksona-Goldthorpe'a-Portocarero) używanych w porównawczych (międzynarodowych) badaniach nad międzypokoleniową ruchliwością społeczną (zmianą własnej pozycji społecznej w porównaniu z pozycją społeczną jednego lub obojga rodziców). W tym celu zostaną omówione wyniki klasycznych oraz najnowszych prac dotyczących mobilności społecznej, przy czym będą to publikacje, które nie zostały jeszcze przetłumaczone na język polski. Szczególnie istotne będą rekomendacje pomocne przy dokonywaniu wyborów politycznych, które mogą mieć przełożenie na szybsze lub wolniejsze tempo ruchliwości społecznej. 


\section{Ruchliwość społeczna w społeczeństwach przemysłowych po dwóch stronach „żelaznej kurtyny"}

Pracą, która natychmiast po ukazaniu się uzyskała status pozycji klasycznej we współczesnych badaniach nad ruchliwością społeczną, jest książka The Constant Flux ${ }^{1}$ (co można przetłumaczyć jako Stała płynność). Jej autorami są dwaj socjolodzy - Szwed Robert Erikson i Brytyjczyk John H. Goldthorpe. Publikacja stanowi podsumowanie wieloletnich badań nad zjawiskiem ruchliwości społecznej prowadzonych zarówno pod kierunkiem jej autorów, jak i przez innych badaczy zajmujących się tą problematyką. Niestety, mimo klasycznego charakteru nadal nie została przetłumaczona na język polski² - co jest podwójną stratą, zważywszy na fakt, iż jej autorzy analizują w niej także przypadek naszego kraju (na podstawie danych zebranych w 1972 r. w badaniach przeprowadzonych przez polskich socjologów $\left.{ }^{3}\right)$. Pozostałe dane użyte do testowania stawianych w książce hipotez dotyczą Australii, Anglii i Walii, Francji, RFN, Węgier, Irlandii, Irlandii Północnej, Japonii, Szkocji, Szwecji i Stanów Zjednoczonych (zebrane w latach 1970-1975) oraz Czechosłowacji (w 1984 r.), Holandii (w latach 1976-1977 i 1982-1985) i Włoch (w latach 1985-1986). Wszystkie pochodzą z badań przeprowadzonych na dużych, reprezentatywnych dla danego społeczeństwa próbach (najmniejsza z nich - włoska - liczyła 1764 respondentów) ${ }^{4}$.

Omawiana książka jest w istocie próbą sprawdzenia w badaniach empirycznych tego, czy teorie mówiące o podobieństwie tempa ruchliwości społecznej w różnych społeczeństwach dają się obronić. Pisząc o takich teoriach, R. Erikson i J.H. Goldthorpe wspominają w tym kontekście o pracach Pitirima Sorokina ${ }^{5}$ oraz Seymoura M. Lipseta i Hansa L. Zetterberga ${ }^{6}$, koncentrują się jednak na - jak sami ją nazywają - hipotezie Feathermana, Jonesa i Hausera ${ }^{7}$. Mówi ona o tym, że badając międzypokoleniową ruchliwość społeczną, należy dokonać rozróżnienia na ruchliwość absolutną i ruchliwość względną. Ruchliwość absolutna to realnie zaobserwowana ruchliwość społeczna w tabeli krzyżowej (pokazującej w wierszach klasę społeczną pochodzenia, a w kolumnach - osiągniętą klasę społeczną). Innymi słowy, ruchliwość absolutna jest mierzona liczbą (lub udziałem procentowym) osób, które doświadczyły mobilności społecznej, czyli w porównaniu z ojcem i/lub matką przesunęły się z jednej klasy społecznej do drugiej (w tabeli krzyżowej znajdują się w komórkach położonych poza przekątną tabeli; komórki

1 R. Erikson, J.H. Goldthorpe, The Constant Flux. A Study of Class Mobility in Industrial Societies, Clarendon Press, Oxford 1993

2 Na szczęście można już się zapoznać z polskim tłumaczeniem wyboru artykułów jednego z autorów The Constant Flux - J.H. Goldthorpe'a (niektóre są poświęcone badaniom nad ruchliwością społeczną). Zob.

J.H. Goldthorpe, O socjologii: integracja badań i teorii, Wydawnictwo IFiS PAN, Warszawa 2012.

3 K. Zagórski, Transformations of Social Structure and Social Mobility in Poland , IInternational Journal of Sociology" 1977, vol. 7, no. 3-4.

4 R. Erikson, J.H. Goldthorpe, op. cit., s. 166.

5 P. Sorokin, Ruchliwość społeczna, Wydawnictwo IFiS PAN, Warszawa 2009.

6 S.M. Lipset, H.L. Zetterberg, Social Mobility in Industrial Societies [w:] Social Mobility in Industrial Society, red. S.M. Lipset, R. Bendix, University of California Press, Berkeley 1959.

7 D.L. Featherman, F.L. Jones, R.M. Hauser, Assumptions of Social Mobility Research in the US: The Case of Occupational Status, "Social Science Research” 1975, vol. 4, no. 4. 
znajdujące się na przekątnej tabeli przedstawiają bowiem te osoby, które w ciągu życia nie zmieniły pierwotnej przynależności klasowej). Ruchliwość względna, zwana przez R. Eriksona i J.H. Goldthorpe'a także „płynnością społeczną”, jest natomiast miarą szans na znalezienie się w danej klasie społecznej w zależności od tego, z której klasy społecznej się wywodzimy. To właśnie ruchliwość względną - a nie ruchliwość absolutną - uznaje się za wskaźnik otwartości danej struktury społecznej, tj. tego, czy szanse na awans społeczny (lub ryzyko społecznej degradacji) są niezależne od klasy społecznej, w której się urodziliśmy ${ }^{8}$. To dlatego względna ruchliwość społeczna (płynność społeczna) jest uznawana w literaturze przedmiotu za wskaźnik równości szans ${ }^{9}$. $Z$ tego też powodu w niniejszym artykule skoncentruję się na opisie badań dotyczących tego właśnie zjawiska, nawet jeśli omawiane tu prace dotyczyły także ruchliwości absolutnej (przemian kształtu struktury klasowej).

Względna ruchliwość społeczna jest miarą powstałą przez zestawienie wartości dwóch ruchliwości absolutnych i wyraża się ją przy użyciu ilorazu szans. Można go obliczyć w najprostszym, 2-klasowym schemacie (klasa wyższa i klasa niższa) w trzech krokach: a) dzieląc liczbę osób wywodzących się z klasy wyższej i należących do tej klasy przez liczbę osób wywodzących się z klasy wyższej i należących do klasy niższej; b) dzieląc liczbę osób wywodzących się z klasy niższej i należących do klasy wyższej przez liczbę osób wywodzących się z klasy niższej i należących do tej klasy; c) dzieląc iloraz uzyskany w pierwszym kroku przez iloraz uzyskany w drugim kroku¹0. Uzyskany w ten sposób iloraz szans równy 1 oznacza sytuację doskonałej ruchliwości społecznej lub pełnej płynności społecznej, w której prawdopodobieństwo znalezienia się w jednej z dwu klas społecznych jest takie samo dla osób pochodzących zarówno z jednej, jak i z drugiej klasy. Natomiast wartość ilorazu szans większa od 1 mówi nam, że osoby urodzone w klasie wyższej mają większe szanse na znalezienie się w tej samej klasie niż osoby urodzone w klasie niższej. Z kolei wartość ilorazu szans mniejsza od 1 wskazuje, że osoby urodzone w klasie wyższej mają mniejsze szanse na znalezienie się w tej samej klasie niż osoby urodzone w klasie niższej ${ }^{11}$.

Zdaniem Davida L. Feathermana, F. Lancastera Jonesa i Roberta M. Hausera na poziom ruchliwości absolutnej (liczbę osób, które zmieniły swoją przynależność klasową) mają wpływ liczne czynniki ekonomiczne, technologiczne i demograficzne, które są w stosunku do procesów odtwarzania się struktury społecznej czynnikami zewnętrznymi. Z tego względu należy się spodziewać, że poziom tej ruchliwości będzie w poszczególnych państwach różny i mocno osadzony w ich społeczno-gospodarczej historii. Natomiast poziom ruchliwości względnej (zróżnicowanie szans, jakie dwie osoby wywodzące się z różnych klas społecznych mają na znale-

8 R. Breen, The Comparative Study of Social Mobility [w:] Social Mobility in Europe, red. R. Breen, Oxford University Press, Oxford 2004, s. 4, https://doi.org/10.1093/0199258457.003.0001.

9 E. Bukodi, M. Paskov, B. Nolan, Intergenerational Class Mobility in Europe: A New Account, „Social Forces” 2020, vol. 98 , no. 3, s. 942.

10 W przypadku tabeli, w której analizujemy ruchliwość społeczną pomiędzy więcej niż dwoma klasami społecznymi, liczba ilorazów szans opisujących względną ruchliwość społeczną pomiędzy wszystkimi możliwymi parami kombinacji klas społecznych jest równa $\left(k^{2}-k\right)^{2} / 4$, gdzie $k$ oznacza liczbę analizowanych klas społecznych. Zob. R. Erikson, J.H. Goldthorpe, op. cit., s. 56.

11 R. Breen, Intergenerational Mobility: Core Model of Social Fluidity [w:] The Blackwell Encyclopedia of Sociology, red. G. Ritzer, Wiley, London 2007, s. 1. 
zienie się w jednej lub drugiej klasie społecznej ${ }^{12}$ ) można traktować jako poziom ruchliwości społecznej „netto”, tj. po uwzględnieniu przemian i procesów gospodarczych, technologicznych i demograficznych. Według wspomnianych badaczy poziom ten - przy założeniu, że mamy do czynienia ze społeczeństwami, w których funkcjonuje gospodarka rynkowa oraz system rodziny małej (dwupokoleniowej) - jest we wszystkich społeczeństwach przemysłowych „praktycznie taki sam"13 . Celem, jaki R. Erikson i J.H. Goldthorpe postawili sobie, pisząc The Constant Flux, było sprawdzenie, czy rzeczywiście taki wspólny, „podstawowy wzór" względnej ruchliwości społecznej daje się zaobserwować w rozwiniętych społeczeństwach przemysłowych - przy czym własną analizę prawdziwości tego modelu rozciągnęli także na społeczeństwa przemysłowe, w których w momencie przeprowadzenia badania nie funkcjonowała gospodarka rynkowa.

Aby zrealizować ten cel, przyjęli w badaniach perspektywę, w której ruchliwość społeczna zachodzi wewnątrz pewnej struktury klasowej, tzn. odnosi się do przemieszczania się jednostek między pozycjami społecznymi definiowanymi przez pozycję zajmowaną na rynku pracy i charakter wykonywanej działalności. Konkretny schemat klasowy, którym R. Erikson i j.H. Goldthorpe posłużyli się w swoich analizach, został stworzony w ich wcześniejszych pracach i w polskiej literaturze przedmiotu jest znany przede wszystkim jako schemat EGP (Eriksona-Goldthorpe'aPortocarero) ${ }^{14}$. Ma on kilka wersji: od pełnej, 11-klasowej do najbardziej ograniczonej, 3-klasowej (pracownicy niefizyczni, pracownicy fizyczni i robotnicy rolni); w The Constant Flux autorzy najczęściej odwołują się jednak do wersji 7-klasowej (przedstawiono ją w tabeli 1, w której opisano również 5-klasową wersję tego schematu, ponieważ w innych omówionych niżej badaniach posłużono się właśnie nią).

Na podstawie analiz przeprowadzonych przy użyciu modeli logarytmiczno-liniowych ${ }^{15}$ R. Erikson i J.H. Goldthorpe doszli do wniosku, że hipoteza Feathermana, Jonesa i Hausera powinna zostać przyjęta, ale w zmodyfikowanej formie. Po przeanalizowaniu danych z dziewięciu badanych przez siebie państw (Anglii, Szkocji, Irlandii Północnej, Irlandii, Francji, RFN, Węgier, Polski i Szwecji) stwierdzili, że model zakładający, iż tempo relatywnej ruchliwości społecznej (mierzonej wartością ilorazu szans) jest w każdym z nich identyczne, wyjaśnia 95\% związku pomiędzy klasą pochodzenia a obecną przynależnością klasową, a jego zastosowanie wobec badanych prowadzi do pomyłki przy przypisaniu obecnej pozycji klasowej na podstawie wcześniejszej pozycji klasowej jedynie w 4\% przypadków. Okazało się zatem, że tempo relatywnej ruchliwości społecznej nie jest - jak przypuszczali D.L. Featherman, F.L. Jones i R.M. Hauser identyczne, lecz bardzo podobne ${ }^{16}$. Analiza przeprowadzona w Australii, Stanach Zjednoczo-

12 Ibidem.

13 D.L. Featherman, F.L. Jones, R.M. Hauser, op. cit., s. 340.

14 R. Erikson, J.H. Goldthorpe, L. Portocarero, Intergenerational Class Mobility in Three Western European Societies: England, France and Sweden, "British Journal of Sociology” 1979, vol. 30, no. 4; R. Erikson, J.H. Goldthorpe, L. Portocarero, Social Fluidity in Industrial Nations: England, France and Sweden , British Journal of Sociology” 1982, vol. 33, no. 1.

15 G. Lissowski, Zastosowanie modeli logarytmiczno-liniowych do analizy zwiq̨zków między wieloma zmiennymi jakościowymi, „Studia Socjologiczne” 1984, t. 2, nr 93; D. Przybysz, Modele logarytmiczno-liniowe dla zmiennych porządkowych. Przykłady zastosowania, „ASK. Społeczeństwo. Badania. Metody” 2004, nr 13.

16 R. Erikson, J.H. Goldthorpe, op. cit., s. 115-116. 
nych, Czechosłowacji, Holandii, Włoszech i Japonii wykazała z kolei, iż tempo relatywnej ruchliwości społecznej w tych krajach jest również zbliżone do wyników uzyskanych w pierwszych dziewięciu przypadkach. Zaproponowana przez autorów The Constant Flux pierwsza z dwóch modyfikacji hipotezy Feathermana, Jonesa i Hausera polega więc na tym, że poziom relatywnej ruchliwości społecznej charakterystyczny dla wszystkich krajów uprzemysłowionych uznaje się za podobny (a nie tożsamy). Istnieje zatem „podstawowy wzór” (core pattern) względnej ruchliwości społecznej w społeczeństwach przemysłowych, od którego istnieją odstępstwa. Używając porównania muzycznego, można powiedzieć: jeśli chodzi o równość szans i otwartość swoich struktur społecznych, społeczeństwa przemysłowe grają tylko jedną melodię, na której temat istnieją jednak pewne wariacje.

\section{Tabela 1. Schemat klasowy EGP w wersji 7-klasowej i 5-klasowej*}

\begin{tabular}{l|l}
\multicolumn{1}{c|}{ Wersja 7-klasowa } & \multicolumn{1}{c|}{ Wersja 5-klasowa } \\
\hline $\begin{array}{l}\text { klasa usługodawców - service class (inteligencja, wyższe } \\
\text { kadry kierownicze przedsiębiorstw i urzędnicy pań- } \\
\text { stwowi, przedstawiciele wielkiego biznesu, specjaliści } \\
\text { w zawodach umysłowych średniego szczebla) }\end{array}$ & „białe kołnierzyki” \\
\hline $\begin{array}{l}\text { pracownicy umysłowi wykonujący rutynowe prace biu- } \\
\text { rowe oraz pracownicy umysłowi w handlu i usługach }\end{array}$ & \\
\hline $\begin{array}{l}\text { drobnomieszczaństwo (rzemieślnicy, właściciele jedno- } \\
\text { osobowych i małych firm poza rolnictwem) }\end{array}$ & drobnomieszczaństwo \\
\hline robotnicy rolni & pracujący w rolnictwie \\
\hline właściciele gospodarstw rolnych & robotnicy wykwalifikowani \\
\hline robotnicy wykwalifikowani (np. brygadziści, mistrzowie) & robotnicy niewykwalifikowani \\
\hline robotnicy niewykwalifikowani &
\end{tabular}

* Oparłem się w części na nomenklaturze, którą do przetłumaczenia pełnej, 11-klasowej wersji schematu EGP zaproponowano w: H. Domański, D. Przybysz, Analiza przydatności schematu EGP jako wskaźnika pozycji społecznej, „ASK. Społeczeństwo. Badania. Metody” 2003, nr 12, s. 89.

Źródło: R. Erikson, J.H. Goldthorpe, The Constant Flux. A Study of Class Mobility in Industrial Societies, Clarendon Press, Oxford 1993, s. 38-39.

W dalszych krokach swojej analizy R. Erikson i J.H. Goldthorpe wykazali, że istniejące pomiędzy 15 badanymi krajami zróżnicowanie poziomu płynności społecznej nie daje się wyjaśnić ani poziomem ich uprzemysłowienia, ani poziomem panujących w nich nierówności edukacyjnych. Różnice w relatywnej ruchliwości społecznej okazały się natomiast powiązane z poziomem nierówności dochodowych: większa płynność społeczna występowała w krajach o mniejszym poziomie nierówności dochodowych. Różnice te do pewnego stopnia są również powiązane z systemem politycznym (niezależnie od poziomu nierówności dochodowych w różnych społeczeństwach): kraje realnego socjalizmu charakteryzowały się szybszym tempem relatywnej ruchliwości społecznej, natomiast ograniczając analizę tylko do społeczeństw kapitalistycznych, nie zaobserwowano związku pomiędzy większą płynnością społeczną a dominacją polityczną 
(rozumianą jako długość sprawowania władzy) partii lewicowych ${ }^{17}$. Z tego względu autorzy The Constant Flux zaproponowali również drugą modyfikację hipotezy Feathermana, Jonesa i Hausera. Ich zdaniem trwałe zaangażowanie siły aparatu współczesnego państwa jest w stanie zmodyfikować (tj. przede wszystkim przyśpieszyć) względną ruchliwość społeczną i tym samym zwiększyć stopień otwartości struktury społecznej w porównaniu z „podstawowym wzorem” dla społeczeństw przemysłowych ${ }^{18}$. Warto dodać, że wyniki późniejszych badań przemawiają za przyjęciem tej drugiej poprawki. Alexi Gugushvilii ${ }^{19}$ przeprowadził analizę danych, które dotyczyły 21 państw postsocjalistycznych (Albanii, Azerbejdżanu, Armenii, Bułgarii, Białorusi, Chorwacji, Estonii, Gruzji, Węgier, Łotwy, Litwy, Macedonii, Mołdawii, Czarnogóry, Polski, Rumunii, Rosji, Serbii, Słowacji, Słowenii i Ukrainy) i pochodziły z Europejskiego Sondażu Wartości ${ }^{20}$ z edycji z 2008 r. W każdym z badanych krajów dane odnosiły się do reprezentatywnej próby o liczebności ok. 1500 respondentów, którzy w chwili wywiadu mieli od 25 do 59 lat. Okazało się, że uprzednia przynależność danego państwa do Związku Radzieckiego nadal wpływa na szybsze tempo ruchliwości społecznej, przy czym ten efekt jest silniejszy w przypadku osób urodzonych w latach 1949-1967 niż w przypadku osób urodzonych w latach 1968-1983. Zdaniem A. Gugushvilego utrzymywanie się tego efektu świadczy o intensywności, z jaką przez długi czas w ZSRR prowadzono - jak on to określa - „polityki destratyfikacyjne”21. Na marginesie należy zauważyć, że otwarte pozostaje pytanie postawione jeszcze w czasach przed transformacją ustrojową: czy owa zmniejszająca się skuteczność radzieckich „polityk destratyfikacyjnych” była efektem tego, że z biegiem lat również w warunkach realnego socjalizmu rodziny dysponujące w jego ramach większymi zasobami ekonomicznymi, kulturalnymi i społecznymi mogły przedsięwziąć skuteczne kontrstrategie mające pomóc im w przekazaniu swoim dzieciom uprzywilejowanej pozycji społecznej, czy też zmniejszenie się płynności społecznej było efektem korekt prowadzonej polityki, uwzględnionych po tym, gdy zorientowano się, że w swym pierwotnym kształcie polityka ta jest dysfunkcjonalna już na poziomie zarządzania zakładami pracy ${ }^{22}$.

\section{Ruchliwość społeczna w Europie w latach 1970-2010}

Analiza danych pochodzących ze 117 badań przeprowadzonych pomiędzy 1970 a 2000 r. w 11 krajach (Francji, Holandii, Irlandii, Izraelu, Niemczech, Norwegii, Polsce, Szwecji, Wielkiej Brytanii, Włoszech i na Węgrzech) na dużych, reprezentatywnych dla danego społeczeństwa próbach pozwoliła na sformułowanie dwóch wniosków ${ }^{23}$. Płynność społeczna ponownie okazała się

17 Ibidem, s. 387.

18 Ibidem, s. 179.

19 A. Gugushvili, Political Democracy, Economic Liberalization and Macro-Sociological Models of Intergenerational Mobility, "Social Science Research” 2017, vol. 66, s. 64.

20 EVS, 2010, European Values Study 2008, 4th Wave, Integrated Dataset, http://dx.doi.org/10.4232/1.10188.

21 A. Gugushvili, op. cit., s. 75.

22 W. Wesołowski, B. Mach, Unfulfilled Systemic Functions of Social Mobility: II. the Polish Case, "International Sociology" 1986, vol. 1, no. 2.

23 R. Breen, R. Luijkx, Social Mobility in Europe between 1970 and 2000 [w:] Social Mobility in Europe, red. R. Breen, Oxford University Press, Oxford 2004, s. 37-38, https://doi.org/10.1093/0199258457.003.0003. 
zjawiskiem stabilnym. Model Feathermana, Jonesa i Hausera, zakładający, że poziom względnej ruchliwości społecznej jest w różnych społeczeństwach przemysłowych taki sam i że w miarę upływu czasu nie podlega zmianom, wyjaśnia 85\% zaobserwowanego związku pomiędzy klasą pochodzenia a aktualną przynależnością klasową ${ }^{24}$ (dla przypomnienia: ten sam model we wcześniejszych badaniach R. Eriksona i J.H. Goldthorpe’a wyjaśniał więcej, bo aż 95\% tego związku). Nowe badanie potwierdziło więc występowanie „podstawowego wzoru” względnej ruchliwości społecznej w społeczeństwach przemysłowych, ale analiza ta (dotycząca większej liczby krajów i późniejszych danych) pokazała, że od wzoru istnieją jednak większe odstępstwa. Ten wyższy stopień zróżnicowania pozwolił wyodrębnić grupę państw o wysokiej płynności społecznej (Izrael, Norwegia, Polska, Szwecja, Węgry), niskiej płynności społecznej (Irlandia, Niemcy i Włochy) i grupę pośrednią (Francja, Holandia i Wielka Brytania) ${ }^{25}$.

Temu zróżnicowaniu płynności społecznej (obojętnie, czy mowa o zróżnicowaniu pomiędzy krajami, czy o zmianach otwartości struktury społecznej w miarę upływu czasu) nie można natomiast przypisać żadnego systematycznego charakteru. Dalsze analizy wykazały bowiem, że nie ma ono związku ani z poziomem nierówności ekonomicznych (mierzonych wartością współczynnika Giniego dla dochodów) ${ }^{26}$, ani z poziomem rozwoju gospodarczego (mierzonego za pomocą wielkości PKB na głowę) ${ }^{27}$, choć płynność społeczna okazała się większa w byłych państwach realnego socjalizmu (Polska i Węgry) i państwach zwykle rządzonych przez partie socjaldemokratyczne (Norwegia i Szwecja) ${ }^{28}$.

Komentując rezultaty tych badań, ich autorzy piszą wprost, że trudność w wyjaśnieniu, skąd biorą się odchylenia od wspólnego dla wszystkich społeczeństw przemysłowych poziomu płynności społecznej, może wynikać stąd, że tempo względnej ruchliwości społecznej nie jest wyłącznie efektem prowadzonej przez poszczególne rządy polityki (np. odmiennego kształtu systemu edukacji czy zróżnicowanych i zmieniających się w czasie zasad regulujących funkcjonowanie rynku pracy), ale może być także odzwierciedleniem przygodnych, historycznych procesów (oraz - o czym nie należy ich zdaniem również zapominać - rodzaju i jakości danych, które badacze mogą wykorzystać) ${ }^{29}$.

Także najnowsze prowadzone badania nad ruchliwością społeczną w Europie potwierdzają (ponownie - z pewnymi modyfikacjami) słuszność wniosków, do których na początku lat 90. XX w. doszli R. Erikson i J.H. Goldthorpe. Wykorzystując dane pochodzące z Europejskiego Sondażu Społecznego ${ }^{30}$ (a konkretniej - z jego edycji z lat 2002-2010), Ersébet Bukodi, Marii Paskov i Brian Nolan ${ }^{31}$ przeanalizowali wzory względnej ruchliwości społecznej dla mężczyzn z 30 państw europejskich (Austrii, Belgii, Bułgarii, Cypru, Czech, Danii, Estonii, Finlandii, Francji,

24 R. Breen, R. Luijkx, Conclusions [w:] Social Mobility in Europe, red. R. Breen, Oxford University Press, Oxford 2004, s. 386, https://doi.org/10.1093/0199258457.003.0015.

25 Ibidem, s. 396.

26 Ibidem.

27 Ibidem, s. 397-398.

28 Ibidem, s. 401.

29 Ibidem, s. 402.

30 Więcej informacji po polsku na temat tego sondażu na stronie internetowej: http://ess.fispan.pl.

31 E. Bukodi, M. Paskov, B. Nolan, op. cit., s. 942. 
Grecji, Hiszpanii, Holandii, Irlandii, Litwy, Luksemburga, Łotwy, Niemiec, Norwegii, Polski, Portugalii, Rosji, Rumunii, Słowacji, Słowenii, Szwajcarii, Szwecji, Ukrainy, Węgier, Wielkiej Brytanii i Włoch). W analizach uwzględniono łącznie 71836 badanych, najmniejsza narodowa próbka pochodziła z Włoch i liczyła 891 respondentów, największa zaś z Niemiec i liczyła 4740. Najstarsi badani urodzili się w 1938 r., a najmłodsi w 1985 r. Obecną przynależność klasową respondenta sklasyfikowano za pomocą Europejskiej Klasyfikacji Społeczno-Ekonomicznej (EKSE, European Socio-Economic Classification) - 7-klasowego schematu opracowanego dla wszystkich krajów europejskich, rozwiniętego na bazie schematu EGP ${ }^{32}$. Natomiast do ustalenia pochodzenia klasowego użyto informacji o pozycji klasowej zajmowanej przez tego z rodziców, który według EKSE zajmował wyższą pozycję społeczną (tzw. podejście dominacyjne ${ }^{33}$ ) wtedy, kiedy respondent miał 14 lat $^{34}$.

Przeprowadzone analizy pozwoliły badaczom na wyodrębnienie trzech grup państw: o wysokim poziomie płynności społecznej (Czechy, Dania, Estonia, Finlandia, Francja, Litwa, Łotwa, Norwegia, Rosja, Rumunia, Słowacja, Słowenia, Szwecja, Ukraina i Wielka Brytania), o niskim poziomie płynności społecznej (Bułgaria, Cypr, Hiszpania, Luksemburg, Niemcy, Polska, Portugalia i Węgry) oraz przejściowych (Austria, Belgia, Grecja, Holandia, Irlandia, Szwajcaria i Włochy) ${ }^{35}$. Poziom otwartości struktury społecznej nie okazał się jednak zależny ani od poziomu rozwoju gospodarczego, ani od poziomu nierówności dochodowych ${ }^{36}$. W komentarzu do wyników swoich badań E. Bukodi, M. Paskov i B. Nolan zwracają uwagę, że w porównaniu z badaniami R. Eriksona i J.H. Goldthorpe'a (odnoszącymi się do pierwszej połowy lat 70.) oraz Richarda Breena i innych (odnoszącymi się do ostatnich trzech dekad XX w.) Polska i Węgry przesunęły się z grupy państw o otwartej strukturze społecznej do grupy państw, w których szanse na zmianę swojego położenia społecznego są niewielkie.

Natomiast ogólna interpretacja uzyskanych wyników, czyli dotycząca wszystkich badanych krajów, sprowadza się - zdaniem E. Bukodi, M. Paskov i B. Nolana - do ponownego potwierdzenia hipotezy Feathermana, Jonesa i Hausera, zmodyfikowanej jednak w następujący sposób: we wszystkich społeczeństwach, w których funkcjonuje kapitalistyczna, wolnorynkowa gospodarka, panuje ustrój liberalnej demokracji i w których występuje system rodziny małej (dwupokoleniowej), istnieją granice, których nie da się przekroczyć w celu zwiększenia tempa względnej ruchliwości społecznej (uczynienia istniejącej struktury społecznej bardziej otwartą). Granice te nie mają jednak charakteru technicznego czy też naturalnego, ale polityczny. W społeczeństwach spełniających trzy powyższe warunki interwencje polityczne zmierzające do wyrównania szans po przekroczeniu pewnego pułapu swojej intensywności mogą bowiem natrafić na skuteczny opór zarówno o charakterze politycznym, jak i w postaci indywidualnych

32 D. Rose, E. Harrison, Social Class in Europe: An Introduction to the European Socio-Economic Classification, Routledge, London 2010; zob. też É. Penissat, J. Rowell, Note de recherché sur la fabrique de la nomenclature socio-économique européene ESeC, "Actes de la recherche en sciences sociales” 2012, vol. 191-192, no. 1.

33 R. Erikson, Social Class of Men, Women and Families, "Sociology” 1984, vol. 18, no. 4.

34 E. Bukodi, M. Paskov, B. Nolan, op. cit., s. 946.

35 Ibidem, s. 963.

36 Ibidem, s. 966. 
czy grupowych (ale niepolitycznych) „strategii dostosowawczych”. Źródłem zaś tego oporu są działania podejmowane przez uprzywilejowane rodziny posiadające zasoby ekonomiczne, społeczne i kulturowe, których zawsze można użyć, by zwiększyć szanse na sukces swoich dzieci czy to w systemie edukacyjnym, czy na rynku pracy ${ }^{37}$. Innymi słowy: w społeczeństwach przemysłowych od „podstawowego wzoru” względnej ruchliwości społecznej istnieje pewien określony zakres odchyleń, zależący od decyzji politycznych, które jednak są podejmowane w ramach ograniczeń narzucanych przez system gospodarczy, ustrój polityczny i strukturę rodziny.

\section{Ruchliwość społeczna w perspektywie porównawczej: jaka rola państwa i polityki?}

Z powyższego przeglądu najważniejszych badań porównawczych nad płynnością społeczną można więc wyciągnąć następujący wniosek: istnieje wspólny dla wszystkich społeczeństw uprzemysłowionych „podstawowy wzór” ruchliwości społecznej, występują jednak pewne odchylenia, które dotyczą poszczególnych krajów i pojawiają się w miarę upływu czasu. Niektóre społeczeństwa charakteryzują się bardziej otwartą, inne natomiast bardziej zamkniętą strukturą klasową ${ }^{38}$, przy czym (co można dostrzec, porównując chociażby wyniki dla Polski i Węgier na przykładzie wcześniejszych badań R. Breena i innych oraz późniejszych badań E. Bukodi, M. Paskov i B. Nolana) z biegiem lat każde społeczeństwo może się przesunąć z jednej grupy do drugiej. Jaką rolę w ustanawianiu wyższego lub niższego poziomu płynności społecznej mogą więc odegrać państwo i polityka, działające w ramach trzech zidentyfikowanych przez E. Bukodi, M. Paskov i B. Nolana ograniczeń?

Próbę odpowiedzi na to pytanie można znaleźć w badaniach Gøsty Espinga-Andersena. Ten duński specjalista zajmujący się kwestią społecznych podstaw gospodarki postindustrialnej39 w swoich ostatnich pracach odpowiada na pytanie o to, w jaki sposób model prowadzonej polityki społecznej wpływa na międzypokoleniowe dziedziczenie przynależności klasowej ${ }^{40}$. W swojej klasycznej już książce o kształtowaniu się i funkcjonowaniu odmiennych modeli państwa dobrobytu ${ }^{41}$ (wydanej w 1990 r.) wyodrębnił on trzy podstawowe ustroje państw opiekuńczych (liberalny - charakterystyczny dla państw anglosaskich; konserwatywny - typowy dla Niemiec, Francji, Włoch i Hiszpanii; socjaldemokratyczny - występujący w najpełniejszej i najbardziej rozbudowanej wersji w krajach skandynawskich). Celem każdego z tych modeli było początkowo zapewnienie (w różny sposób) opieki społecznej i stabilizacji dochodów, a nie zmiana struktury klasowej czy zwiększenie jej otwartości. Dopiero pod koniec XX w. w ramach modelu

37 Ibidem, s. 967-968.

38 M. Hout, T.A. DiPrete, What Have We Learned: RC28's Contributions to Knowledge about Social Stratification, „Research in Social Stratification and Mobility" 2006, vol. 24, no. 1, s. 3-5.

39 G. Esping-Andersen, Społeczne podstawy gospodarki postindustrialnej, Wydawnictwo Wyższej Szkoły Pedagogicznej TWP, Warszawa 2010.

40 G. Esping-Andersen, Welfare Regimes and Social Stratification, "Journal of European Social Policy" 2015, vol. 25, no. 1; zob. też G. Esping-Andersen, S. Wagner, Asymmetries in the Opportunity Structure. Intergenerational Mobility Trends in Europe, „Research in Social Stratification and Mobility” 2012, vol. 30, no. 4.

41 G. Esping-Andersen, Trzy światy kapitalistycznego państwa dobrobytu, Difin, Warszawa 2010. 
socjaldemokratycznego można, zdaniem G. Espinga-Andersena, zaobserwować zwiększenie się równości szans - zresztą jako uboczny skutek reform wprowadzanych w celach innych niż zwiększenie otwartości struktury klasowej ${ }^{42}$.

Aby sprawdzić, czy odrębne modele państwa opiekuńczego przekładają się na różnice w tempie międzypokoleniowej względnej ruchliwości społecznej, G. Esping-Andersen sięgnął do pochodzących z 2006 r. danych z badania European Union Statistics on Income and Living Conditions ${ }^{43}$. Analizę ograniczył do mężczyzn, porównując kohorty urodzonych w latach 19451957 i 1968-1977 z Danii, Francji, Hiszpanii, Norwegii i Włoch. Obecną przynależność klasową respondenta i jego pochodzenie klasowe opisał, używając 5-klasowej wersji schematu EGP, przy czym w swoich analizach skoncentrował się na klasie w tym modelu najwyższej („białych kołnierzyków") i najniższej (robotników niewykwalifikowanych), a jako grupę odniesienia przyjął trzy pozostałe klasy łącznie. Pierwsze pytanie, które zadał w swoim artykule, dotyczyło tego, jak w każdym z badanych państw zmieniał się w zależności od kohorty wpływ pochodzenia klasowego na szanse zdobycia wykształcenia wyższego. Drugie pytanie badawcze dotyczyło tego, jak w poszczególnych państw zmieniał się w zależności od kohorty wpływ pochodzenia klasowego na uzyskiwany dochód (prawdopodobieństwo znalezienia się w jednym z pięciu kwintyli dochodu).

O ile wśród osób urodzonych w latach 1945-1957 w każdym z badanych krajów bycie synem robotnika niewykwalifikowanego zmniejszało szanse na zdobycie wykształcenia wyższego, o tyle w przypadku osób z późniejszej kohorty ten negatywny wpływ niskiego pochodzenia społecznego kompletnie zanikł w Danii i Norwegii, znacząco zmniejszył się we Włoszech i Hiszpanii i pozostał mniej więcej taki sam we Francji. Natomiast jeśli chodzi o urodzenie się w klasie „białych kołnierzyków", to wiązało się ono z ułatwionym dostępem do wykształcenia wyższego w obydwu kohortach we wszystkich badanych państwach ${ }^{44}$. Analiza danych dotyczących osiąganego dochodu ukazała podobny wzór: niezależnie od kraju synowie robotników niewykwalifikowanych urodzeni w latach 1945-1957 byli narażeni na podobne ryzyko znalezienia się w dolnym kwintylu dochodów. Natomiast w przypadku urodzonych pomiędzy 1968 a 1977 r. ten negatywny efekt pochodzenia z najniższej klasy społecznej uległ zmniejszeniu w Danii i zwłaszcza w Norwegii, natomiast utrzymał się w pozostałych krajach. Z kolei w starszej kohorcie prawdopodobieństwo znalezienia się w górnym kwintylu dochodów związane z pochodzeniem z klasy „białych kołnierzyków" było największe w Hiszpanii, a następnie kolejno we: Francji, Włoszech, Norwegii i Danii. W młodszej kohorcie natomiast ten dochodowy efekt uprzywilejowania zmniejszył się (choć nie zanikł) we wszystkich badanych państwach z wyjątkiem Danii, gdzie z kolei uległ wzmocnieniu ${ }^{45}$. Uzyskany w analizie danych dla obydwu krajów skandynawskich wzór G. Esping-Andersen nazywa „asymetrycznym wyrównywaniem”. Polega ono, jego zdaniem, na tym, że Dania i Norwegia skutecznie zwiększyły szanse na awans społeczny osób wywodzących się z dołu struktury społecznej bez naruszania przywilejów i przewag, którymi cieszą się osoby wywodzące

42 G. Esping-Andersen, Welfare Regimes, op. cit., s. 125.

43 Więcej na temat tej bazy danych na stronie internetowej: https://ec.europa.eu/eurostat/web/microdata/ european-union-statistics-on-income-and-living-conditions.

44 G. Esping-Andersen, Welfare Regimes, op. cit., s. 130.

45 Ibidem, s. 131. 
się z wyższych klas społecznych. W innych analizowanych społeczeństwach natomiast takiego zjawiska otwarcia się szans na awans społeczny w klasach niższych nie zaobserwowano. Zdaniem duńskiego naukowca nie ma jednej przyczyny występowania tej rozbieżności pomiędzy społeczeństwami, które wykształciły odmienne typy ustrojowe swoich państw opiekuńczych. Jego zdaniem można ją jednak po części wyjaśnić skutkiem reform społecznych podejmowanych od lat 60. XX w. w krajach skandynawskich, nierealizowanych natomiast - lub jedynie na znacznie mniejszą skalę - w krajach o innym modelu państwa opiekuńczego. Z jednej strony były to reformy systemu edukacji: eliminacja selekcji wewnątrzszkolnej - ścieżkowania (ang. tracking) na grupy uczące się według różnych programów (np. ogólnego i zawodowego); stworzenie powszechnego systemu kształcenia ogólnego na poziomie szkoły średniej; usuwanie barier finansowych na wszystkich szczeblach edukacji. W odniesieniu do tych reform można powiedzieć, że zwiększenie szans na awans społeczny przedstawicieli klas niższych było jednym z ich zamierzonych efektów. Z drugiej strony natomiast „asymetryczne wyrównanie” szans na awans społeczny jest - zdaniem G. Espinga-Andersena - niezamierzonym efektem ubocznym reform podejmowanych w zupełnie innych celach. Ma on tu na myśli przede wszystkim reformy zmierzające do osiągnięcia pełnej równości płciowej, motywowanej chęcią zwiększenia poziomu aktywności zawodowej kobiet, które próbowano osiągnąć przede wszystkim za pomocą narzędzi należących do dziedziny polityki rodzinnej i wsparcia zatrudnienia kobiet. Można tu wymienić rozwinięcie systemu urlopów rodzicielskich i rozbudowanie szczodrych i uniwersalnych zasiłków na dziecko (co zlikwidowało biedę wśród dzieci, także wśród dzieci wychowywanych przez samotnych rodziców) i powszechnego (i - co ważne - wysokiej jakości) systemu opieki nad dziećmi w wieku przedszkolnym. Zamierzonym celem tej reformy była chęć pomocy kobietom w godzeniu macierzyństwa z aktywnością zawodową, niezamierzonym zaś efektem - zapewnienie dzieciom urodzonym w klasach niższych odpowiedniej stymulacji poznawczo-behawioralnej na najwcześniejszym (a więc najważniejszym) etapie życia - stymulacji, której najprawdopodobniej zabrakłoby im w ich rodzinnych domach.

\section{Podsumowanie}

Celem tego artykułu było: po pierwsze, przedstawienie wyników zarówno klasycznych, jak i najnowszych badań porównawczych nad ruchliwością społeczną, które nie zostały jeszcze przetłumaczone na język polski, po drugie zaś, refleksja nad tym, jakiego typu wnioski dla polityki prowadzonej przez państwo mogą wynikać z owych badań.

Podstawowym podziałem dokonywanym w socjologicznych badaniach nad międzypokoleniową ruchliwością społeczną jest rozróżnienie ruchliwości absolutnej i względnej. Tę pierwszą mierzy się liczbą osób (lub ich procentowym udziałem), które przesunęły się z jednej klasy społecznej do drugiej w porównaniu z klasą społeczną zajmowaną przez ojca i/lub matkę najczęściej w chwili, gdy sami badani byli nastolatkami. Ruchliwość względna, powstała przez zestawienie ze sobą wartości dwóch ruchliwości absolutnych, zwana też płynnością społeczną, jest natomiast miarą szans na znalezienie się w danej klasie społecznej w zależności od pochodzenia klasowego. To ten drugi typ ruchliwości - wyrażany za pomocą ilorazu szans - jest 
uznawany za wskaźnik otwartości danej struktury społecznej oraz odzwierciedlenie panującej w danym społeczeństwie równości szans. Dlatego też w tym artykule skupiono się na omówieniu wyników badań dotyczących względnej ruchliwości społecznej. W przytaczanych tu studiach klasę społeczną definiowano przy użyciu oryginalnego lub zmodyfikowanego schematu klasowego EGP, w którym przynależność jednostki do konkretnej klasy społecznej jest wyznaczana na podstawie pozycji zajmowanej przez tę jednostkę na rynku pracy oraz charakteru wykonywanej przez nią pracy.

Przedstawione wyniki badań, opartych na reprezentatywnych próbach zebranych na przestrzeni lat 1970-2010 i pochodzących z licznych krajów o różnej historii społeczno-gospodarczej i politycznej, pozwalają na przyjęcie zmodyfikowanej hipotezy Feathermana, Jonesa i Hausera. Mianowicie: we wszystkich społeczeństwach przemysłowych istnieje pewien „podstawowy wzór" względnej ruchliwości społecznej, od którego istnieją odstępstwa, tj. można wyróżnić społeczeństwa o wyższym i niższym poziomie względnej ruchliwości społecznej. Stopień i kierunek tych odchyleń (to, czy struktura społeczna jest w danym kraju bardziej, czy mniej otwarta) zależą jednak nie tyle od ogólnego poziomu rozwoju gospodarczego, ile od decyzji politycznych. Należy zauważyć, że decyzje polityczne z kolei nie są podejmowane w próżni - w warunkach gospodarki rynkowej i liberalnej demokracji nie da się skutecznie prowadzić polityk, które zwiększałyby tempo względnej ruchliwości społecznej do tego stopnia, by zagrozić dziedziczeniu uprzywilejowanej pozycji społecznej przez dzieci z klas wyższych. W tych warunkach wykonalne i zależne od woli politycznej jest prowadzenie działań zmierzających do osiągnięcia stanu „asymetrycznego wyrównania”. Polega on na tym, iż zwiększa się szanse na awans społeczny osób wywodzących się z dołu struktury społecznej bez jednoczesnego naruszania przywilejów i przewag, którymi cieszy się potomstwo klas wyższych. Jak wskazują doświadczenia Duńczyków i Norwegów, do stanu tego można się przybliżyć, z jednej strony realizując konsekwentnie i przez lata reformy systemu edukacji (poprzez jego demokratyzację, polegającą nie tylko na eliminacji barier finansowych na wszystkich jego szczeblach, lecz również na usuwaniu podziałów na grupy uczące się według różnych - ogólnokształcących i zawodowych - programów na poziomie szkoły średniej), a z drugiej - prowadząc politykę równości płci (pomoc w godzeniu macierzyństwa i aktywności zawodowej, np. w postaci systemu urlopów rodzicielskich i rozbudowy powszechnego systemu opieki przedszkolnej).

\section{Bibliografia}

Breen R., Intergenerational Mobility: Core Model of Social Fluidity [w:] The Blackwell Encyclopedia of Sociology, red.

G. Ritzer, Wiley, London 2007, http://dx.doi.org/10.1002/9781405165518.wbeosi057.

Breen R., The Comparative Study of Social Mobility [w:] Social Mobility in Europe, red. R. Breen, Oxford University

Press, Oxford 2004, https://doi.org/10.1093/0199258457.003.0001.

Breen R., Luijkx R., Social Mobility in Europe between 1970 and 2000 [w:] Social Mobility in Europe, red. R. Breen,

Oxford University Press, Oxford 2004, https://doi.org/10.1093/0199258457.003.0003.

Bukodi E., Paskov M., Nolan B., Intergenerational Class Mobility in Europe: A New Account, "Social Forces” 2020, vol. 98, no. 3, https://doi.org/10.1093/sf/soz026. 
Domański H., Przybysz D., Analiza przydatności schematu EGP jako wskaźnika pozycji społecznej, „ASK. Społeczeństwo. Badania. Metody" 2003, nr 12.

Erikson R., Social Class of Men, Women and Families, "Sociology” 1984, vol. 18, no. 4, https://doi.org/10.1177/00 38038584018004003.

Erikson R., Goldthorpe J.H., The Constant Flux. A Study of Class Mobility in Industrial Societies, Clarendon Press, Oxford 1993.

Erikson R., Goldthorpe J.H., Portocarero L., Intergenerational Class Mobility in Three Western European Societies: England, France and Sweden, „British Journal of Sociology” 1979, vol. 30, no. 4.

Erikson R., Goldthorpe J.H., Portocarero L., Social Fluidity in Industrial Nations: England, France and Sweden, „British Journal of Sociology" 1982, vol. 33, no. 1.

Esping-Andersen G., Społeczne podstawy gospodarki postindustrialnej, Wydawnictwo Wyższej Szkoły Pedagogicznej TWP, Warszawa 2010.

Esping-Andersen G., Trzy światy kapitalistycznego państwa dobrobytu, Difin, Warszawa 2010.

Esping-Andersen G., Welfare Regimes and Social Stratification, "Journal of European Social Policy" 2015, vol. 25, no. 1, https://doi.org/10.1177/0958928714556976.

Esping-Andersen G., Wagner S., Asymmetries in the Opportunity Structure. Intergenerational Mobility Trends in Europe, "Research in Social Stratification and Mobility” 2012, vol. 30, no. 4, https://doi.org/10.1016/j. rssm.2012.06.001.

EVS, 2010, European Values Study 2008, 4th Wave, Integrated Dataset, https://dx.doi.org/10.4232/1.10188.

Featherman D.L., Jones F.L., Hauser R.M., Assumptions of Social Mobility Research in the US: The Case of Occupational Status, „Social Science Research” 1975, vol. 4, no. 4, https://doi.org/10.1016/0049-089x(75)90002-2.

Goldthorpe J.H., O socjologii: integracja badań i teorii, Wydawnictwo IFiS PAN, Warszawa 2012.

Gugushvili A., Political Democracy, Economic Liberalization and Macro-Sociological Models of Intergenerational Mobility, "Social Science Research” 2017, vol. 66, https://doi.org/10.1016/j.ssresearch.2017.06.003.

Hout M., DiPrete T.A., What Have We Learned: RC28's Contributions to Knowledge about Social Stratification, „Research in Social Stratification and Mobility” 2006, vol. 24, no. 1, https://doi.org/10.1016/j.rssm.2005. 10.001.

Lipset S.M., Zetterberg H.L., Social Mobility in Industrial Societies [w:] Social Mobility in Industrial Society, red. S.M. Lipset, R. Bendix, University of California Press, Berkeley 1959.

Lissowski G., Zastosowanie modeli logarytmiczno-liniowych do analizy zwiq̨zków między wieloma zmiennymi jakościowymi, „Studia Socjologiczne” 1984, t. 2, nr 93.

Penissat É., Rowell J., Note de recherché sur la fabrique de la nomenclature socio-économique européene ESeC, "Actes de la recherche en sciences sociales" 2012, vol. 191-192, no. 1.

Przybysz D., Modele logarytmiczno-liniowe dla zmiennych porządkowych. Przykłady zastosowania , „ASK. Społeczeństwo. Badania. Metody" 2004, nr 13.

Rose D., Harrison E., Social Class in Europe: An Introduction to the European Socio-Economic Classification, Routledge, London 2010.

Social Mobility in Europe, red. R. Breen, Oxford University Press, Oxford 2004, https://doi.org/10.1093/019925 8457.001.0001.

Sorokin P., Ruchliwość społeczna, Wydawnictwo IFiS PAN, Warszawa 2009. 
Wesołowski W., Mach B., Unfulfilled Systemic Functions of Social Mobility: II. the Polish Case, „International Sociology" 1986, vol. 1, no. 2, https://doi.org/10.1177/026858098600100204.

Zagórski K., Transformations of Social Structure and Social Mobility in Poland, "International Journal of Sociology” 1977, vol. 7, no. 3-4, http://dx.doi.org/10.1080/15579336.1977.11769672. 